\title{
Postpollination changes in floral odor in Silene latifolia Adaptive mechanisms for seed-predator avoidance?
}

\section{Journal Article}

Author(s):

Muhlemann, Joëlle K.; Waelti, Marc O.; Widmer, Alex (D); Schiestl, Florian P.

Publication date:

2006-08

Permanent link:

https://doi.org/10.3929/ethz-b-000001949

Rights / license:

In Copyright - Non-Commercial Use Permitted

Originally published in:

Journal of Chemical Ecology 32(8), https://doi.org/10.1007/s10886-006-9113-0 


\title{
Postpollination Changes in Floral Odor in Silene latifolia: Adaptive Mechanisms for Seed-Predator Avoidance?
}

\author{
Joëlle K. Muhlemann • Marc O. Waelti • \\ Alex Widmer • Florian P. Schiestl
}

Received: 2 March 2006 / Revised: 12 May 2006 /

Accepted: 24 May 2006/Published online: 29 June 2006

(C) Springer Science + Business Media, Inc. 2006

\begin{abstract}
Floral odor is a key trait for pollinator attraction in many plants, but may also direct antagonists like herbivores to flowers. In this study, we examined how floral scent changes after pollination in Silene latifolia, which has a specialized relationship with the seed predator Hadena bicruris. We found an overall decrease in total scent emission and considerable changes in relative amounts of scent compounds after pollination. Lilac aldehydes A and B as well as veratrole contributed most to the decrease in scent emission. These three compounds are known to be key signals for the attraction of H. bicruris to the flowers. A specific downregulation of these compounds may increase the reproductive success of the plant by reducing seed predation after pollination.
\end{abstract}

Keywords Silene latifolia $\cdot$ Floral scent $\cdot$ Postpollination $\cdot$ Lilac aldehydes $\cdot$ Veratrole $\cdot$ Seed predation

\section{Introduction}

In plants, mating involves the movement of pollen from one individual to another. A large number of flowering plants rely on animal pollinators to ensure pollen movement and reproductive success, and produce different signals such as shape, color, and odor to attract them to the flowers. So far, pollination biologists have devoted their studies mainly to shape and color, but compared to these signals, little is known about odor as a signal for pollinator attraction. Scent, however, has been found to act as a signal in many plant-pollinator interactions, and a large diversity of floral scent compounds have been described.

Odor is a floral trait that varies greatly within a species, as well as between species. The intensity and ratios of compounds in flower scent changes over the life span, depending on age (Dudareva et al., 2000), pollination status (Tollsten and Bergström, 1989; Tollsten, 1993; Schiestl et al., 1997; Schiestl and Ayasse, 2001; Negre et al., 2003; Dötterl

J. K. Muhlemann $(\bowtie) \cdot$ M. O. Waelti $\cdot$ A. Widmer $\cdot$ F. P. Schiestl

Plant Ecological Genetics, Institute of Integrative Biology, ETH Zurich, 8092 Zurich, Switzerland e-mail: joelle.muhlemann@gmx.ch 
et al., 2005; Theis and Raguso, 2005), and circadian rhythms (e.g., Dötterl et al., 2005; Negre et al., 2003).

Of particular interest is the variation in scent emission before and after pollination. Postpollination changes in scent production reduce metabolic costs and decrease the attractiveness of the flower, thus directing the pollinator to other flowers of the plant and increasing overall reproductive success (Schiestl and Ayasse, 2001). In Silene latifolia Poiret (Caryophyllaceae), a perennial native to Europe, postpollination changes may have the additional function of reducing the attraction of seed predators (Dötterl et al., 2005). S. latifolia has a close relationship with Hadena bicruris Hufnagel (Lepidoptera, Noctuidae), with $H$. bicruris designated as a parasitic pollinator. The female moths pollinate the female flowers. After nectar ingestion, they lay their eggs in the flower. The larvae subsequently feed on the developing seeds (Bopp and Gottsberger, 2004). Usually, there is one larva hatching per vessel. Once the larva has eaten the whole seed set, it moves to another intact vessel (personal observation). Adult female moths are attracted to flowers mainly by scent, and lilac aldehydes A-D and veratrole were found to be key compounds in their attraction (Dötterl et al., 2006). These compounds make up about $80 \%$ of the total blend (Table 1).

If postpollination changes are adaptive in terms of reducing the attraction of seed predators, a specific downregulation of the behaviorally active compounds should be observed. The present study aimed at analyzing compositional and quantitative changes in the floral scent emission of S. latifolia after pollination. Furthermore, we analyzed whether pollinatorattracting and nonattracting compounds changed differently in the pollinated flowers.

\section{Methods and Materials}

\section{Plant Material and Sample Size}

Sixteen potted female plants were grown from seeds collected in 2003 from a S. latifolia population located in Leuk (Switzerland). The inflorescence of each potted plant was separated into two equal parts of 3-10 flowers. One part of each inflorescence was handpollinated, whereas the other remained unpollinated. Pollination was achieved at 7 p.m. by dabbing a female flower with a male flower. We used only female flowers that underwent anthesis $24 \mathrm{hr}$ before treatment. Older flowers and buds were removed.

\section{Scent Collection}

Floral scent was collected during the first and second night after pollination, from 8 p.m. to 7 a.m. Each treated inflorescence was separately packed in an oven-baking bag (PET, Toppits $^{\circledR}$ ). A filter was placed inside the bag and connected to a vacuum pump (Personal Air Sampler, SKC Inc.) drawing the air at a rate of about $140 \mathrm{ml} / \mathrm{min}$. Air in the bag was drawn over the filter consisting of $5 \mathrm{mg}$ of Porapak Q as an adsorbent material, sealed in a small glass tube. Nine filters were connected by silicone tubes to one vacuum pump, one of them sampling surrounding air to identify background contamination. Before scent collection, filters were cleaned with $100 \mu \mathrm{l}$ dichloromethane and $100 \mu \mathrm{l}$ hexane. After sampling, desorption was achieved by slowly running $50 \mu \mathrm{l}$ of a hexane/acetone mixture $(9 / 1)$ through the filter. Desorption was carried out immediately after sampling. Eluates were stored at $-20^{\circ} \mathrm{C}$ in sealed glass vials for later analysis. 
Before analysis, $100 \mathrm{ng}$ of n-octadecane (Fluka, Buchs) were added to each sample as an internal standard. One microliter of the eluate was injected splitless at a start temperature of $50^{\circ} \mathrm{C}$ into a gas chromatograph (Agilent $6890 \mathrm{~N}$ ) equipped with an HP5 column $(30 \mathrm{~m} \times$ $0.32 \mathrm{~mm} \times 0.25 \mu \mathrm{m})$ and a flame ionization detector. Hydrogen was used as the carrier gas and nitrogen as make-up gas. The injector temperature was kept at $300^{\circ} \mathrm{C}$. The oven was kept at $50^{\circ} \mathrm{C}$ for $1 \mathrm{~min}$, then heated to $150^{\circ} \mathrm{C}$ at a rate of $5^{\circ} \mathrm{C} / \mathrm{min}$, and subsequently to $300^{\circ} \mathrm{C}$ at a rate of $10^{\circ} \mathrm{C} / \mathrm{min}$, and kept at $300^{\circ} \mathrm{C}$ for $10 \mathrm{~min}$. Chromatograms were analyzed with the program ChemStation (Agilent Technologies). Absolute amounts of compounds were quantified by using the internal standard (IS) method, i.e., by integrating the peak of every substance and dividing every peak area with the integrated IS peak area and multiplying with the IS amount. None of the samples of surrounding air contained considerable amounts of one of the compounds used in our analyses. Thus, we did not subtract these samples. For a few samples, gas chromatographic analyses with mass selective detection (Hewlett Packard G1800 A) were conducted by using identical column and oven parameters. Compounds were identified by comparison of retention times and gas chromatography-mass spectrometry (GC-MS) spectra with those of known standard compounds.

Data were first checked for normality (Shapiro-Wilk test) and homogeneity of variances (Levene test) and then analyzed with $t$ test and ANOVA.

\section{Results and Discussion}

We found 28 odor compounds in our samples, 2 of which belong to the class of fatty acid derivates (nonanal and octanal), 8 to the class of benzoids (benzyl acetate, benzaldehyde, benzyl benzoate, methyl benzoate, 2-methoxyphenol, methyl salicylate, phenylacetaldehyde, phenylethyl alcohol, and veratrole), and 12 to the class of terpenoids (camphene, eucalyptol, lilac aldehyde A, lilac aldehyde B, lilac aldehyde C, limonene, linalool, 6methyl-5-hepten-2-one, trans- $\beta$-ocimene, $\alpha$-pinene, $\beta$-pinene, and $\beta$-farnesene) (see also Dötterl et al., 2005). Five of the reported compounds remained unidentified (Table 1).

Pollinated plants emitted significantly lower total scent amounts over the two nights than unpollinated plants (unpollinated: mean $\pm \mathrm{SE}, 408.90 \pm 105.33 \mathrm{ng} \cdot \mathrm{h}^{-1} \cdot \mathrm{l}^{-1} \cdot$ flower $^{-1}$; pollinated: mean $\pm \mathrm{SE}, 95.68 \pm 29.55 \mathrm{ng} \cdot \mathrm{h}^{-1} \cdot \mathrm{l}^{-1} \cdot$ flower $^{-1} ; t$ test: $t=2.86, d f=60, P<$ 0.01). Earlier studies on postpollination changes have also found a decrease in total scent emission. Tollsten and Bergström (1989) and Tollsten (1993), for example, detected a decrease in scent production of Platanthera bifolia. In Ophrys sphegodes, the scent emission also decreased after pollination (Schiestl et al., 1997). In two thistle species, scent decreased strongly after pollination leading to reduced attractiveness of the flowers to honey bees (Theis and Raguso, 2005). Dötterl et al. (2005) showed that S. latifolia almost completely stopped emitting scent only $24 \mathrm{hr}$ after pollination. In our study, there was an approximately fourfold decrease in total scent emission (see above). Lilac aldehydes A and $\mathrm{B}$ as well as veratrole, which made up about $80 \%$ of total scent emission before pollination, contributed most to this decrease (Fig. 1). Most of the other compounds remained unchanged after pollination (Fig. 1). In terms of relative amounts, pollinated plants sampled on the first and second night emitted significantly lower proportions of lilac aldehydes A and B than unpollinated plants sampled in the first night [lilac aldehyde A: ANOVA, $F(3,58)=6.21$, 
Table 1 Mean ( \pm SE) relative amounts (\%) of odor compounds in pollinated and nonpollinated plants of $S$. latifolia over two nights

\begin{tabular}{|c|c|c|c|c|}
\hline \multirow[t]{2}{*}{ Compound } & \multicolumn{2}{|l|}{ Nonpollinated } & \multicolumn{2}{|l|}{ Pollinated } \\
\hline & First night & Second night & First night & Second night \\
\hline \multicolumn{5}{|l|}{ Fatty acid derivates } \\
\hline Octanal & $0.56 \pm 0.14 \mathrm{bc}$ & $0.59 \pm 0.13 \mathrm{bc}$ & $1.77 \pm 0.29 \mathrm{a}$ & $1.30 \pm 0.23 \mathrm{ab}$ \\
\hline Nonanal $^{\mathrm{a}}$ & $0.29 \pm 0.04 \mathrm{bc}$ & $0.77 \pm 0.15 \mathrm{bc}$ & $1.46 \pm 0.30 \mathrm{a}$ & $1.96 \pm 0.33 \mathrm{ab}$ \\
\hline Octanal & $0.56 \pm 0.14 \mathrm{bc}$ & $0.59 \pm 0.13 b c$ & $1.77 \pm 0.29 \mathrm{a}$ & $1.30 \pm 0.23 \mathrm{ab}$ \\
\hline \multicolumn{5}{|l|}{ Benzoids } \\
\hline Benzaldehyde $^{a}$ & $2.19 \pm 0.29 b c$ & $3.12 \pm 0.61 \mathrm{bc}$ & $7.70 \pm 0.99 \mathrm{a}$ & $6.92 \pm 1.11 \mathrm{ab}$ \\
\hline Phenylacetaldehyde ${ }^{a}$ & $0.95 \pm 0.19 \mathrm{bd}$ & $1.41 \pm 0.36 \mathrm{abd}$ & $2.85 \pm 0.81 \mathrm{acd}$ & $3.33 \pm 0.83 \mathrm{ac}$ \\
\hline 2-Methoxyphenol ${ }^{\mathrm{a}}$ & $0.14 \pm 0.03 \mathrm{ab}$ & $0.39 \pm 0.10 \mathrm{bc}$ & $0.29 \pm 0.10 \mathrm{abc}$ & $0.54 \pm 0.20 \mathrm{ac}$ \\
\hline Methyl benzoate ${ }^{\mathrm{a}}$ & $0.09 \pm 0.03 \mathrm{a}$ & $0.21 \pm 0.08 \mathrm{a}$ & $0.09 \pm 0.05 \mathrm{a}$ & $0.50 \pm 0.14 \mathrm{c}$ \\
\hline Phenylethyl alcohol $^{\mathrm{a}}$ & $0.16 \pm 0.04 \mathrm{bc}$ & $0.18 \pm 0.09 \mathrm{bc}$ & $0.67 \pm 0.15 \mathrm{a}$ & $0.62 \pm 0.15 \mathrm{ab}$ \\
\hline Veratrole $^{\mathrm{a}}$ & $15.66 \pm 4.48 \mathrm{~b}$ & $11.08 \pm 3.08 \mathrm{ab}$ & $4.21 \pm 0.99 \mathrm{a}$ & $7.92 \pm 3.68 \mathrm{ab}$ \\
\hline Methyl salicylate ${ }^{a}$ & $1.05 \pm 0.14 \mathrm{bd}$ & $2.39 \pm 0.60 \mathrm{abd}$ & $4.19 \pm 0.77 \mathrm{acd}$ & $5.37 \pm 0.88 \mathrm{ac}$ \\
\hline Benzyl benzoate & $1.44 \pm 0.62 \mathrm{a}$ & $1.14 \pm 0.59 \mathrm{a}$ & $0.68 \pm 0.14 \mathrm{a}$ & $1.23 \pm 0.15 \mathrm{a}$ \\
\hline \multicolumn{5}{|l|}{ Terpenoids } \\
\hline$\alpha$-Pinene & $0.16 \pm 0.05 \mathrm{ab}$ & $0.66 \pm 0.15 \mathrm{ad}$ & $0.53 \pm 0.13 \mathrm{abd}$ & $1.53 \pm 0.26 \mathrm{c}$ \\
\hline Camphene & $0.74 \pm 0.09 \mathrm{~b}$ & $2.52 \pm 0.59 \mathrm{a}$ & $2.94 \pm 0.42 \mathrm{a}$ & $5.71 \pm 0.89 \mathrm{c}$ \\
\hline$\beta$-Pinene & $0.31 \pm 0.05 \mathrm{bc}$ & $0.51 \pm 0.12 \mathrm{bc}$ & $1.30 \pm 0.20 \mathrm{a}$ & $1.17 \pm 0.19 \mathrm{ab}$ \\
\hline 6-Methyl-5-hepten-2-one & $0.25 \pm 0.04 \mathrm{bc}$ & $0.37 \pm 0.11 \mathrm{bc}$ & $1.06 \pm 0.23 \mathrm{a}$ & $1.13 \pm 0.22 \mathrm{ab}$ \\
\hline Limonene & $0.40 \pm 0.14 \mathrm{ab}$ & $1.13 \pm 0.29 \mathrm{abc}$ & $1.50 \pm 0.27 \mathrm{abc}$ & $2.50 \pm 0.97 \mathrm{ac}$ \\
\hline Eucalyptol & $2.50 \pm 0.45 \mathrm{~b}$ & $1.41 \pm 0.41 \mathrm{~b}$ & $9.25 \pm 1.48 \mathrm{a}$ & $3.06 \pm 0.58 \mathrm{~b}$ \\
\hline trans- $\beta$-Ocimene $^{\mathrm{a}}$ & $1.46 \pm 1.22 \mathrm{a}$ & $2.18 \pm 1.09 \mathrm{a}$ & $0.85 \pm 0.21 \mathrm{a}$ & $2.64 \pm 0.56 \mathrm{a}$ \\
\hline Linalool $^{\mathrm{a}}$ & $0.20 \pm 0.04 b c$ & $0.43 \pm 0.09 \mathrm{bc}$ & $1.07 \pm 0.20 \mathrm{a}$ & $0.84 \pm 0.17 \mathrm{ab}$ \\
\hline Lilac aldehyde $\mathrm{A}^{\mathrm{a}}$ & $22.69 \pm 1.93 \mathrm{~b}$ & $16.77 \pm 2.52 \mathrm{ab}$ & $13.80 \pm 2.42 \mathrm{ac}$ & $9.24 \pm 2.09 \mathrm{ac}$ \\
\hline Lilac aldehyde $\mathrm{B}^{\mathrm{a}}$ & $41.45 \pm 2.85 \mathrm{~b}$ & $32.99 \pm 4.71 \mathrm{ab}$ & $23.98 \pm 4.04 \mathrm{ac}$ & $18.78 \pm 4.50 \mathrm{ac}$ \\
\hline $\begin{array}{l}\text { Lilac aldehyde } \mathrm{C} \\
\text { and benzyl acetate }\end{array}$ & $2.68 \pm 0.36 \mathrm{bc}$ & $3.54 \pm 0.40 \mathrm{bc}$ & $6.27 \pm 0.70 \mathrm{a}$ & $5.90 \pm 0.70 \mathrm{ab}$ \\
\hline$\beta$-Farnesene & $0.11 \pm 0.04 \mathrm{abd}$ & $0.43 \pm 0.17 \mathrm{abcd}$ & $0.09 \pm 0.05 \mathrm{abd}$ & $0.74 \pm 0.22 \mathrm{~cd}$ \\
\hline \multicolumn{5}{|c|}{ Unknowns with Kovats retention index, $R_{i}$} \\
\hline U1 978 & $1.08 \pm 0.16 \mathrm{bc}$ & $2.16 \pm 0.42 b c$ & $4.11 \pm 0.52 \mathrm{a}$ & $4.60 \pm 0.68 \mathrm{ab}$ \\
\hline U2 992 & $1.98 \pm 0.89 \mathrm{ab}$ & $12.21 \pm 3.59 \mathrm{ad}$ & $6.15 \pm 1.77 \mathrm{abd}$ & $10.09 \pm 2.47 \mathrm{c}$ \\
\hline U3 1009 & $0.15 \pm 0.04 \mathrm{a}$ & $0.43 \pm 0.10 \mathrm{a}$ & $0.52 \pm 0.15 \mathrm{a}$ & $0.93 \pm 0.14 \mathrm{a}$ \\
\hline U4 1112 & $0.11 \pm 0.05 \mathrm{a}$ & $0.12 \pm 0.05 \mathrm{a}$ & $0.18 \pm 0.07 \mathrm{a}$ & $0.04 \pm 0.03 \mathrm{a}$ \\
\hline U5 1191 & $1.22 \pm 0.27 \mathrm{~b}$ & $0.85 \pm 0.26 b$ & $2.51 \pm 0.40 \mathrm{a}$ & $1.41 \pm 0.21 \mathrm{~b}$ \\
\hline
\end{tabular}

Different letters indicate significant differences between groups as calculated by one-way ANOVA with LSD post hoc test, $P<0.05$.

${ }^{a}$ Compounds elicit electrophysiological signals (Dötterl et al., 2006).

${ }^{\mathrm{b}}$ As lilac aldehyde $\mathrm{C}$ and benzyl acetate coelute and the amounts of benzyl acetate are much lower than the amounts of lilac aldehyde C, they are listed together in the class of terpenoids.

$P=0.001$; Lilac aldehyde B: ANOVA, $F(3,58)=5.84, P=0.001]$. Unpollinated plants sampled on the second night, however, emitted the same relative amounts of lilac aldehydes $\mathrm{A}$ and $\mathrm{B}$ as pollinated plants sampled on the first and second night [lilac aldehyde A: ANOVA, $F(3,58)=6.21, P=0.001$; lilac aldehyde B: ANOVA, $F(3,58)=5.84, P=0.001]$. This could be due to senescence in flowers. For most of the other compounds, pollinated plants emitted the same or greater relative amounts than unpollinated ones (Table 1). 


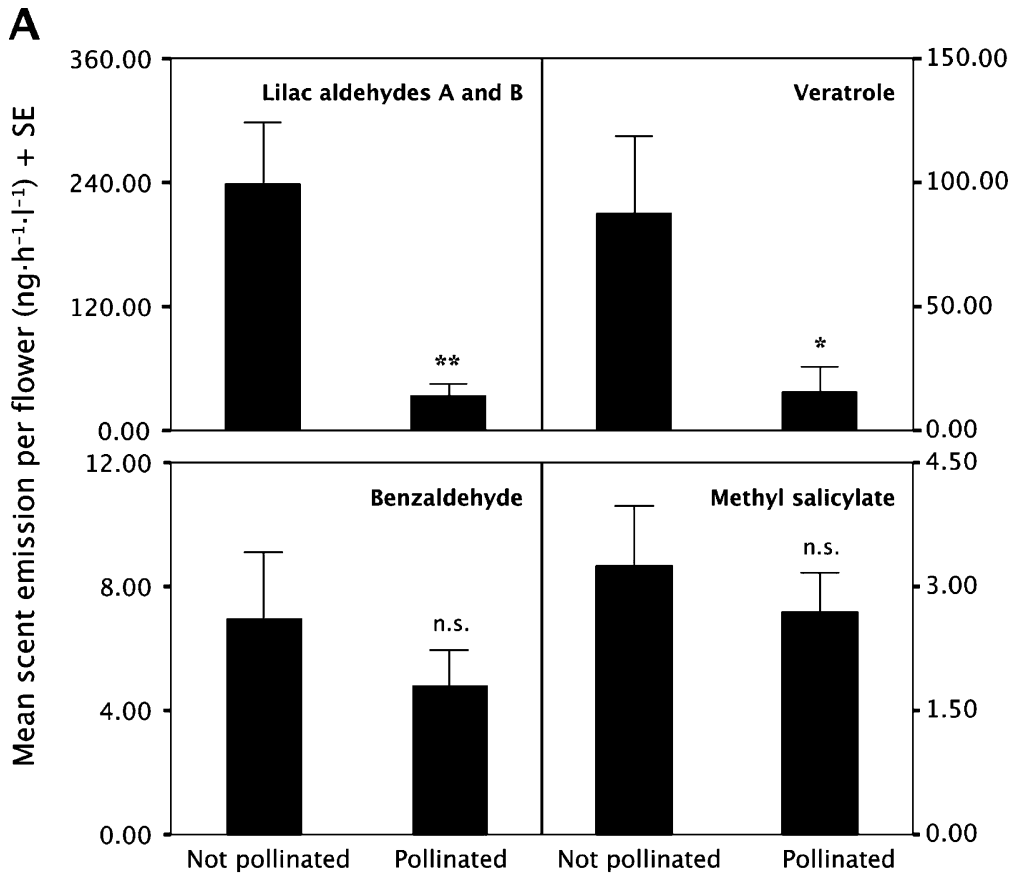

B

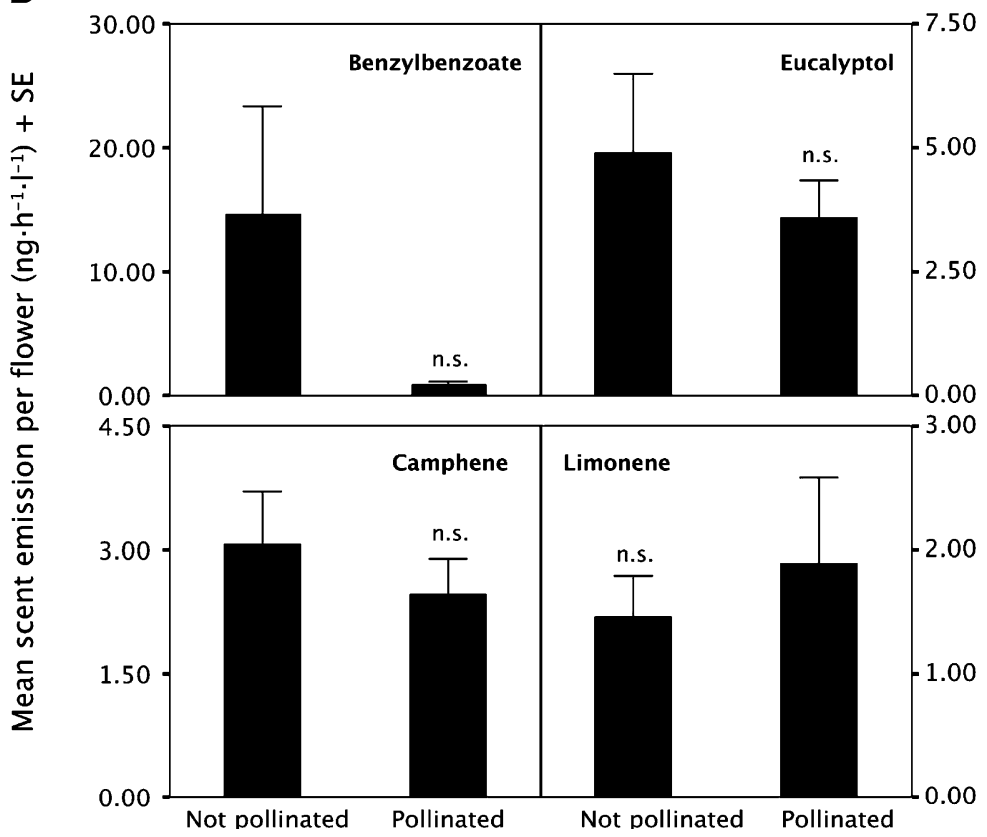

Fig. 1 Mean (+ SE) absolute amounts of (a) the four most abundant electrophysiologically active scent compounds and (b) the four most abundant electrophysiologically nonactive compounds (Dötterl et al., 2006) sampled over the 2 days. Lilac aldehydes A and B and veratrole significantly decreased after pollination $(* t$ test: $t=2.20, d f=60, P<0.05$; **t test: $t=3.33, d f=60, P<0.01)$, whereas the other six analyzed compounds did not change significantly after pollination ( $t$ test, $d f=60, P>0.05$, n.s.) 
There are contradictory results on compositional changes in scent emission reported in the literature. In $P$. bifolia, the relative amounts of scent compounds remained almost constant after pollination (Tollsten and Bergström, 1989; Tollsten, 1993). By contrast, pollination changed the bouquet composition of Cirsium repandum (Theis and Raguso, 2005) and $O$. sphegodes (Schiestl et al., 1997). Interestingly, in the latter species, the emission of farnesyl hexanoate, which functions as a repellent compound for the pollinator (Schiestl and Ayasse, 2001), increases after pollination. This mechanism is thought to direct pollinators to other, as yet unpollinated flowers, thereby maximizing the overall reproductive success of the plant. The strong compositional changes in the floral odor of $S$. latifolia are mostly due to a decrease in lilac aldehydes A and B as well as in veratrole. Since these compounds have been demonstrated to be of key importance for host finding in S. latifolia (Dötterl et al., 2006), we interpret their drastic reduction after pollination as a mechanism for avoiding or reducing further parasitism by the nursery pollinator $H$. bicruris.

Taken together, our results show how adaptations in the chemical communication between plants and their pollinators can be fine-tuned to the regulation of specific compounds in the odor bouquet. Furthermore, our findings underline the key functions of the lilac aldehydes and veratrole for plants' reproductive success, which is largely determined by the attraction of pollinators and avoidance of seed predators.

Acknowledgements We thank Stefan Dötterl (Bayreuth) and Roman Kaiser (Dübendorf) for providing reference compounds used in this study. We are grateful to the reviewers who provided useful comments.

\section{References}

Bopp, S. and Gottsberger, G. 2004. Importance of Silene latifolia ssp. alba and S. dioica (Caryophyllaceae) as host plants of the parasitic pollinator Hadena bicruris (Lepidoptera, Noctuidae). Oikos 105:221-228.

Dötterl, S. Jürgens, A. Seifert, K. Laube, T. Weissbecke, B., and SchütZ, S. 2006. Nursery pollination by a moth in Silene latifolia: the role of odours in eliciting antennal and behavioural responses. New Phytol. 169:707-718.

DöTterL, S., WOLFE, L. M., and JÜrGENS, A. 2005. Qualitative and quantitative analyses of flower scent in Silene latifolia. Phytochemistry 66:203-213.

Dudareva, N., Murfitt, L. M., Mann, C. J., Gorenstein, N., Kolosova, N., Kish, C. M., Bonham, C., and WooD, K. 2000. Developmental regulation of methyl benzoate biosynthesis and emission in snapdragon flowers. Plant Cell 12:949-961.

Negre, F., Kish, C. M., Boatright, J., Underwood, B., Shibuya, K., Wagner, C., Clark, D. G., and DudAREVA, N. 2003. Regulation of methylbenzoate emission after pollination in snapdragon and petunia flowers. Plant Cell 15:2992-3006.

SCHIESTL, F. P. and AyAsse, M. 2001. Post-pollination emission of a repellent compound in a sexually deceptive orchid: a new mechanism for maximising reproductive success? Oecologia 126:531-534.

Schiestl, F. P., Ayasse, M., Paulus, H. F., Erdmann, D., and Francke, W. 1997. Variation of floral scent emission and postpollination changes in individual flowers of Ophrys sphegodes subsp. sphegodes. J. Chem. Ecol. 23:2881-2895.

Theis, N. and Raguso, R. A. 2005. The effect of pollination on floral fragrance in thistles. J. Chem. Ecol. 31:2581-2600.

TOLLSTEN, L. 1993. A multivariate approach to postpollination changes in the floral scent of Platanthera bifolia (Orchidaceae). Nord. J. Bot. 13:495-499.

TOllsten, L. and BergStRöM, J. 1989. Variation and post-pollination changes in floral odors released by Platanthera bifolia (Orchidaceae). Nord. J. Bot. 9:359-362. 